\begin{tabular}{|c|c|}
\hline$\sigma_{\infty}^{\infty}$ & $\begin{array}{c}\text { International Journal of Trend in Scientific } \\
\text { Research and Development (IJTSRD) }\end{array}$ \\
\hline $\begin{array}{lll}0 & 0\end{array}$ & International Open Access Journal \\
\hline 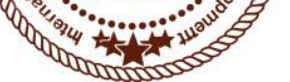 & ISSN No: 2456 - 6470 | www.ijtsrd.com | Volume - 2 | Issue - 1 \\
\hline
\end{tabular}

\title{
Power Quality Standards, Problems and their Solutions
}

\author{
Navneet Kaur \\ M.Tech Scholar, Electrical Engineering Department \\ YIET, Gadhauli, Yamunanagar, Haryana
}

\author{
Gagan Deep Yadav \\ A.P., Electrical Engineering Department \\ YIET, Gadhauli, Yamunanagar, Haryana
}

\begin{abstract}
Recently, power quality has become an important subject and area of research because of its increasing awareness and impacts on the consumers, manufacturers, and utilities. There are a number of economic and reliability issues for satisfactory operation of electrical equipment. As power quality problems are increasing manifold due to the use of solid-state controllers, which cannot be dispensed due to many financial benefits, energy conservation, and other production benefits, the research and development in mitigation techniques for power quality problems is also becoming relevant and important to limit the pollution of the supply system. In such a situation, it is quite important to study the causes, effects, and mitigation techniques for power quality problems. In this paper different power quality standards like standards such as IEEE 519-1992, IEC 61000 , and many others in different countries have been developed on the permissible limits in the levels of deviations and distortions in various electrical quantities such as voltage, current, and power factor are being discussed. Further power quality problems and their possible solutions are also discussed.
\end{abstract}

Keywords: power quality, voltage profile, flicker, IEEE standards, harmonics.

\section{INTRODUCTION}

The term electric power quality (PQ) is generally used to assess and to maintain the good quality of power at the level of generation, transmission, distribution, and utilization of AC electrical power. Since the pollution of electric power supply systems is much severe at the utilization level, it is important to study at the terminals of end users in distribution systems. There are a number of reasons for the pollution of the AC supply systems, including natural ones such as lightening, flashover, equipment failure, and faults (around 60\%) and forced ones such as voltage distortions and notches (about $40 \%$ ). A number of customer's equipment also pollute the supply system as they draw non-sinusoidal current and behave as nonlinear loads [1]. Therefore, power quality is quantified in terms of voltage, current, or frequency deviation of the supply system, which may result in failure or mal-operation of customer's equipment. Typically, some power quality problems related to the voltage at the point of common coupling (PCC) where various loads are connected are the presence of voltage harmonics, surge, spikes, notches, sag/dip, swell and so on [2,3].

These power quality problems cause failure of capacitor banks, increased losses in the distribution system and electric machines, noise, vibrations, overvoltages and excessive current due to resonance, negative sequence currents in generators and motors, especially rotor heating, de-rating of cables, dielectric breakdown, interference with communication systems, signal interference and relay and breaker malfunctions, false metering, interferences to the motor controllers and digital controllers, and so on[4,5]. These power quality problems have become much more serious with the use of solid-state controllers, which cannot be dispensed due to benefits of the cost and size reduction, energy conservation, ease of control, low wear and tear, and other reduced maintenance requirements in the modern electric equipment. Unfortunately, the electronically controlled energy-efficient industrial and commercial electrical loads are most sensitive to power quality problems and they themselves generate power quality problems due to the use of solid-state 
controllers in them[6,7]. Because of these problems, power quality has become an important area of study in electrical engineering, especially in electric distribution and utilization systems. It has created a great challenge to both the electric utilities and the manufacturers. Utilities must supply consumers with good quality power for operating their equipment satisfactorily, and manufacturers must develop their electric equipment either to be immune to such disturbances or to override them. A number of techniques have evolved for the mitigation of these problems either in existing systems or in equipment to be developed in the near future.

\section{Power Quality Standards}

There has been exponentially growing interest in power quality (PQ) in the past quarter century, which may be witnessed by the published literature in terms of research publications, texts, standards, patents, and so on. Some of the main reasons for this have been enhanced sensitivity of equipment, awareness of consumers, increased cost of electricity globally, increased use of solid-state controllers in energy intensive equipment with the aim of energy conservation, power loss reduction, better utilization of utility assets, environmental pollution such as interference to telecommunication systems, malfunction of protection systems, and so on[10,11].
The power quality problems affect the customers in a number of ways such as economic penalty in terms of power loss, equipment failure, mal-operation, interruption in the process, and loss of production. In view of these facts, various terms and definitions are used to quantify the power quality problems in terms of different performance indices. Moreover, a number of standards have been developed by various organizations and institutes that are enforced on the customers, manufacturers, and utilities to maintain an acceptable level of power quality. At present, there is a long list of standards on various aspects of power quality, such as permissible level of deviations, mitigation, and monitoring. Some of them are given here; however, new standards are continuously being developed, with modifications in the existing ones on various aspects such as limits, monitoring, and mitigation devices. Several standards such as IEEE 519-1992, IEC 61000, and many others in different countries have been developed on the permissible limits in the levels of deviations and distortions in various electrical quantities such as voltage, current, and power factor. Moreover, there are several standards on the level of power quality in specific equipment such as lighting and variable-frequency drives in many countries. Table 1 shows a list of some currently available standards on various aspects of power quality[12,13].

\section{TABLE I. LIST OF SOME STANDARDS ON VARIOUS ISSUES OF POWER QUALITY [8]}

\begin{tabular}{|c|c|}
\hline Standard & Description \\
\hline $\begin{array}{l}\text { IEEE Standard 519- } \\
1992\end{array}$ & $\begin{array}{l}\text { Recommended Practices and Requirements for Harmonic Control in Electrical Power } \\
\text { Systems. }\end{array}$ \\
\hline $\begin{array}{l}\text { IEEE Standard } \\
\text { 1159-1995 }\end{array}$ & Recommended Practice for Monitoring Electric Power Quality. \\
\hline $\begin{array}{l}\text { IEEE } \\
1100-1999\end{array}$ & sitive Flectronic $\mathrm{F}$ \\
\hline $\begin{array}{l}\text { IEEE Standard } \\
\text { 1250-1995 }\end{array}$ & Guide for Service to Equipment Sensitive to Momentary Voltage Disturban \\
\hline $\begin{array}{l}\text { IEEE Standard } \\
\text { 1366-2012 }\end{array}$ & Electric Power Distribution Reliability Indices \\
\hline IEC 61000-2-2 & $\begin{array}{l}\text { Compatibility Levels for Low Frequency Conducted Disturbances and Signaling in } \\
\text { Public Supply Systems. }\end{array}$ \\
\hline IEC 61000-2-4 & Compatibility Levels in Industrial Plants for Low-Frequency Conducted Disturbances. \\
\hline IEC 61000-3-2 & $\begin{array}{l}\text { Limits for Harmonic Current Emissions (Equipment Input Current Up to and Including } \\
\text { 16A Per Phase). }\end{array}$ \\
\hline IEC 61000-4-15 & Flicker Meter - Functional and Design Specifications. \\
\hline EN 50160 & Voltage Characteristics of Public Distribution Systems. \\
\hline
\end{tabular}


If power quality problems increase to a level that these start affecting not only those who are creating them, but also other consumers, then it becomes a matter of concern. In view of these power pollution problems, a number of organizations such as IEC, IEEE, American National Standards Institute (ANSI), British Standards (BS), European Norms (EN), Computer Business Equipment Manufacturers Association (CBEMA), and Information Technology Industry Council (ITIC) have developed different standards to specify the permissible limits of various performance indices to maintain the level of power quality to an acceptable benchmark and to provide guidelines to the customers, manufactures, and utilities on curbing the various events causing the power quality problems. Tables II show some important limits on voltages and currents in these standards[14].

\section{TABLE II. IEEE STANDARDS 519-1992: CURRENT DISTORTION LIMITS FOR GENERAL} DISTRIBUTION SYSTEM [21]

\begin{tabular}{|c|l|l|l|l|l|l|}
\hline \multicolumn{7}{|c|}{ Maximum harmonic current distortion (in \% of $\mathrm{I}_{\mathrm{L}}$ ) } \\
\hline \multicolumn{7}{|c|}{ Individual harmonic distortion (odd harmonics) } \\
\hline $\mathrm{I}_{\mathrm{SC}} / \mathrm{I}_{\mathrm{L}}$ & $\mathbf{h}<\mathbf{1 1}$ & $\mathbf{1 1} \leq \mathbf{h}<\mathbf{1 7}$ & $\mathbf{1 7} \leq \mathbf{h}<\mathbf{2 3}$ & $\mathbf{2 3} \leq \mathbf{h 3 5}$ & $\mathbf{3 5} \leq \mathbf{h}$ & $\mathbf{T D D} \mathbf{( \% )}$ \\
\hline$<\mathbf{2 0}$ & 4.0 & 2.0 & 1.5 & 0.6 & 0.3 & 5.0 \\
\hline $\begin{array}{c}\mathbf{2 0} \text { to } \\
<\mathbf{5 0}\end{array}$ & 7.0 & 3.5 & 2.5 & 1.0 & 0.5 & 8.0 \\
\hline $\begin{array}{c}\mathbf{5 0} \text { to } \\
<\mathbf{1 0 0}\end{array}$ & 10.0 & 4.5 & 4.0 & 1.5 & 0.7 & 12.0 \\
\hline $\begin{array}{c}\mathbf{1 0 0} \text { to } \\
<\mathbf{1 0 0 0}\end{array}$ & 12.0 & 5.5 & 5.0 & 2.0 & 1.0 & 15.0 \\
\hline$>\mathbf{1 0 0 0}$ & 15.0 & 7.0 & 6.0 & 2.5 & 1.4 & 20.0 \\
\hline
\end{tabular}

\section{CLASSIFICATION OF POWER QUALITY PROBLEM}

There are a number of power quality problems in the present-day fast-changing electrical systems. These may be classified on the basis of events such as transient and steady state, the quantity such as current, voltage, and frequency, or the load and supply systems. The transient types of power quality problems include most of the phenomena occurring in transient nature (e.g., impulsive or oscillatory in nature), such as sag (dip), swell, short-duration voltage variations, power frequency variations, and voltage fluctuations. The steady-state types of power quality problems include long-duration voltage variations, waveform distortions, unbalanced voltages, notches, DC offset, flicker, poor power factor, unbalanced load currents, load harmonic currents, and excessive neutral current

The second classification can be made on the basis of quantity such as voltage, current, and frequency. For the voltage, these include voltage distortions, flicker, notches, noise, sag, swell, unbalance, under voltage, and overvoltage; similarly for the current, these include reactive power component of current, harmonic currents, unbalanced currents, and excessive neutral current.

The third classification of power quality problems is based on the load or the supply system. Normally, power quality problems due to nature of the load (e.g., fluctuating loads such as furnaces) are load current consisting of harmonics, reactive power component of current, unbalanced currents, neutral current, DC offset, and so on. The power quality problems due to the supply system consist of voltage- and frequency related issues such as notches, voltage distortion, unbalance, sag, swell, flicker, and noise. These may also consist of a combination of both voltage- and current-based power quality problems in the system. The frequency related power quality problems are frequency variation above or below the desired base value. These affect the performance of a number of loads and other equipment such as transformers in the distribution system.

\section{Causes of Power Quality Problems}

There are a number of power quality problems in the present-day fast-changing electrical systems. The main 
causes of these power quality problems can be classified into natural and man-made in terms of current, voltage, frequency, and so on. The natural causes of poor power quality are mainly faults, lightening, weather conditions such as storms, equipment failure, and so on. However, the man-made causes are mainly related to loads or system operations. The causes related to the loads are nonlinear loads such as saturating transformers and other electrical machines, or loads with solid-state controllers such as vapor lamp-based lighting systems, ASDs, UPSs, arc furnaces, computer power supplies, and TVs. The use of various $\mathrm{AC}-\mathrm{DC}$ and $\mathrm{AC}-\mathrm{AC}$ converters of buck, boost, buck-boost, multilevel, and multipulse types with unidirectional and bidirectional power flow capability in the input stage of these equipment and providing suitable circuits for specific applications have changed the scenario of power quality improvement techniques and the features of these systems. The causes of power quality problems related to system operations are switching of transformers, capacitors, feeders, and heavy loads. The natural causes result in power quality problems that are generally transient in nature, such as voltage sag (dip), voltage distortion, swell, and impulsive and oscillatory transients. However, the manmade causes result in both transient and steady-state types of power quality problems. Table 1.1 lists some of the power quality problems and their causes.

However, one of the important power quality problems is the presence of harmonics, which may be because of several loads that behave in a nonlinear manner, ranging from classical ones such as transformers, electrical machines, and furnaces to new ones such as power converters in vapor lamps, switched-mode power supplies (SMPS), ASDs using AC-DC converters, cycloconverters, AC voltage controllers, HVDC transmission, static VAR compensators, and so on.

The techniques employed for power quality improvements in exiting systems facing power quality problems are classified in a different manner from those used in newly designed and developed equipment. These mitigation techniques are further sub-classified for the electrical loads and supply systems, since both of them have somewhat different kinds of power quality problems. In existing nonlinear loads, having the power quality problems of poor power factor, harmonic currents, unbalanced currents, and an excessive neutral current, a series of power filters of various types such as passive, active, and hybrid in shunt, series, or a combination of both configurations are used externally depending upon the nature of loads such as voltage-fed loads, current-fed loads, or a combination of both to mitigate these problems.

\section{Effects of Power Quality Problems on Users}

The power quality problems have been present since the inception of electric power. There have been several conventional techniques for mitigating the power quality problems and in many cases even the equipment are designed and developed to operate satisfactorily under some of the power quality problems. However, recently the awareness of the customers toward the power quality problems has increase tremendously. The power quality problems affect all concerned utilities, customers, and manufacturers directly or indirectly in terms of major financial losses due to interruption of process, equipment damage, production loss, wastage of raw material, loss of important data, and so on. There are many instances and applications such as automated industrial processes, namely, semiconductor manufacturing, pharmaceutical industries, and banking, where even a small voltage dip/sag causes interruption of process for several hours, wastage of raw material, and so on. Some power quality problems affect the protection systems and result in mal-operation of protective devices. These interrupt many operations and processes in the industries and other establishments. These also affect many types of measuring instruments and metering of the various quantities such as voltage, current, power, and energy. Moreover, these problems affect the monitoring systems in much critical, important, emergency, vital, and costly equipment. Harmonic currents increase losses in a number of electrical equipment and distribution systems and cause wastage of energy, poor utilization of utilities' assets such as transformers and feeders, overloading of power capacitors, noise and vibrations in electrical machines, and disturbance and interference to electronics appliances and communication networks. 
TABLE III. POWER QUALITY PROBLEMS, CAUSES AND EFFECTS. [15-23]

\begin{tabular}{|c|c|c|c|c|}
\hline Problem & Category & Categorization & Causes & Effects \\
\hline Transients & Impulsive & $\begin{array}{l}\text { Peak, rise time } \\
\text { and duration }\end{array}$ & $\begin{array}{l}\text { Lightining strike, } \\
\text { transformer } \\
\text { enerization }\end{array}$ & $\begin{array}{l}\text { Power System } \\
\text { resonance }\end{array}$ \\
\hline $\begin{array}{c}\text { Short duration } \\
\text { voltage variations }\end{array}$ & Sag & $\begin{array}{l}\text { Magnitude, } \\
\text { duration }\end{array}$ & $\begin{array}{l}\text { Motor starting, single } \\
\text { line to ground fault }\end{array}$ & $\begin{array}{l}\text { Protection } \\
\text { malfunction loss of } \\
\text { production }\end{array}$ \\
\hline $\begin{array}{l}\text { Lonng duration } \\
\text { voltage variations }\end{array}$ & $\begin{array}{l}\text { Sustained } \\
\text { interruption }\end{array}$ & Duration & Faults & Loss of production \\
\hline Voltage imbalance & $\begin{array}{l}\text { Sustained } \\
\text { interruption }\end{array}$ & $\begin{array}{l}\text { Magnitude, } \\
\text { duration }\end{array}$ & $\begin{array}{l}\text { Switching of loads, } \\
\text { single phasing }\end{array}$ & $\begin{array}{l}\text { Increased losses, } \\
\text { heating of motors }\end{array}$ \\
\hline Voltage flicker & Noise & THD & Arc furnace & $\begin{array}{l}\text { Protection } \\
\text { malfunction }\end{array}$ \\
\hline $\begin{array}{l}\text { Power frequency } \\
\text { varitions }\end{array}$ & & & $\begin{array}{l}\text { Faults, islanding } \\
\text { operation }\end{array}$ & Damage to generator \\
\hline
\end{tabular}

\section{Power Quality Improvement Techniques}

In view of increased problems due to power quality in terms of financial loss, loss of production, wastage of raw material, and so on, a wide variety of mitigation techniques for improving the power quality have evolved in the past quarter century. These include passive components such as capacitors, reactors, custom power devices, a series of power filters, improved power quality AC-DC converters, and matrix converters.

However, the power quality problems may not be because of harmonics in many situations such as in distribution systems where problems of poor voltage regulation, low power factor, load unbalancing, excessive neutral current, and so on are observed. Some of these power quality problems such as poor power factor because of reactive power requirements may be mitigated using lossless passive elements such as capacitors and reactors. Moreover, the custom power devices such as DSTATCOMs, DVRs, and UPQCs are extensively used for mitigating the current, voltage, or both types of power quality problems. In the presence of harmonics in addition to other power quality problems, a series of power filters of various types such as active, passive, and hybrid in shunt, series, or a combination of both configurations in single-phase two-wire, three-phase three-wire, and three-phase fourwire systems are used externally as retrofit solutions for mitigating power quality problems through compensation of nonlinear loads or voltage-based

power quality problems in the AC mains. Since there are a large number of circuits of filters, the best configuration of the filter is decided depending upon the nature of loads such voltage-fed loads, current-fed loads, or a combination of both to mitigate their problems. Power quality improvement techniques used in newly designed and developed equipment are based on the modification of the input stage of these systems with PFC converters, also known as IPQCs, multipulse AC-DC converters, matrix converters for AC-DC or $\mathrm{AC}-\mathrm{AC}$ conversion, and so on, which inherently mitigate some of the power quality problems in them and in the supply system by drawing clean power from the utility. There are a large number of circuits of the converters of boost, buck, buck-boost, multilevel, and multipulse types for unidirectional and bidirectional power flow with and without isolation in single-phase and three-phase supply systems to suit very specific applications. These are used as front end converters in the input stage as a part of the total equipment and in many situations they make these equipment immune to power quality problems in the supply system.

\section{Conclusions}

Because of increased awareness of power quality and its associated problems, standardization, assessment, monitoring, and mitigation have become almost essential for manufacturers, customers, utilities, and researchers. In view of these power quality issues, a number of organizations such as IEC and IEEE have published different standards to specify the permissible limits of various power quality indices to limit the level of power quality to an acceptable benchmark and to provide guidelines to the customers, manufactures, and utilities on curbing the various events causing the power quality problems. Similarly, a number of 
instruments for monitoring and assessing the power quality indices are developed by many manufactures with different names such as power quality analyzers, monitors, and meters for assessing at customer sites, utility premises, and manufacturing stages of various electrical equipment. Because of direct or indirect penalty and loss of revenue, not only power quality mitigation is used at the retrofit level, but also many manufactures have started introducing it in their equipment. This exhaustive exposure of these standards, definitions, monitoring, and assessment of power quality will be beneficial to the designers, users, manufacturers, and research engineers dealing with power quality improvement

\section{References}

1) Bollen, H.J. (2001) Understanding Power Quality Problems, 1st edn, Standard Publishers Distributors, New Delhi.

2) Schlabbach, J., Blume, D., and Stephanblome, T. (2001) Voltage Quality in Electrical Power Systems, Power Engineering and Energy Series, IEEE Press.

3) Om Krishan, Sathans (2016), Frequency regulation in a standalone wind-diesel hybrid power system using pitch-angle controller. 3rd International Conference on Computing for Sustainable Global Development (INDIACom).

4) Sankaran, C. (2002) Power Quality, CRC Press, New York.

5) Kolar, J.W. and Sun, J. (2001) Three-phase power factor correction technology. Seminar $1 \& 4$, PESC'01.

6) Singh, B., Singh, B.N., Chandra, A. et al. (2003) A review of single-phase improved power quality AC-DC converters. IEEE Transactions on Industrial Electronics, 50(5), 962-981.

7) Singh, B., Singh, B.N., Chandra, A. et al. (2004) A review of three-phase improved power quality $\mathrm{AC}-$ DC converters. IEEE Transactions on Industrial Electronics, 51(3), 641-660.

8) IEEE Standard 1159-2009 (2009) IEEE Recommended Practice for Monitoring Electric Power Quality, IEEE.

9) IEEE Working Group on Nonsinusoidal Situations (1996) Practical definitions for powers in systems with nonsinusoidal waveforms and unbalanced loads: a discussion. IEEE Transactions on Power Delivery, 11(1), 79-101.
10) Heydt, G.T. (1994) Electric Power Quality, 2nd edn, Stars in a Circle Publications, West Lafayette, IN. IEC 61000-3-2 (1995) Electromagnetic Compatibility (EMC) - Part 3: Limits - Section 2: Limits for Harmonic Current Emissions (Equipment Input Current <16 A Per Phase), IEC.

11) IEEE Standard 1159-1995 (1995) IEEE Recommended Practice for Monitoring Electric Power Quality, IEEE.

12) Paice, D.A. (1996) Power Electronic Converter Harmonics, IEEE Press, New York.

13) Arrillaga, J., Smith, B.C., Watson, N.R., and Wood, A.R. (1997) Power System Harmonic Analysis, John Wiley \& Sons, Ltd, Chichester, UK.

14) Porter, G.J. and Sciver, J.A.V. (eds) (1999) Power Quality Solutions: Case Studies for Troubleshooters, The Fairmont Press, Inc., Lilburn, GA.

15) Arrillaga, J., Watson, N.R., and Chen, S. (2000) Power System Quality Assessment, John Wiley \& Sons, Inc., New York.

16) Duffey, C.K. and Stratford, R.P. (1989) Update of harmonic standard IEEE-519: IEEE recommended practices and requirements for harmonic control in electric power systems. IEEE Transactions on Industry Applications, 25(6), 1025-1034.

17) Miller, T.J.E. (1982) Reactive Power Control in Electric Systems, John Wiley \& Sons, Inc., Toronto, Canada, pp. 32-48.

18) Clark, J.W. (1990) AC Power Conditioners Design and Applications, Academic Press, San Diego, CA.

19) IEC SC 77A (1990) Draft Revision of Publication IEC 555-2: Harmonics, Equipment for Connection to the Public Low Voltage Supply System, IEC.

20) Heydt, G.T. (1991) Electric Power Quality, Stars in a Circle Publications, West Lafayette, IN.

21) IEEE Standard 519-1992 (1992) IEEE Recommended Practices and Requirements for Harmonic Control in Electric Power Systems, IEEE.

22) Kazibwe, W.E. and Sendaula, M.H. (1993) Electrical Power Quality Control Techniques, Van Nostrand Reinhold Company. Power Quality Problems and Mitigation Techniques

23) Heydt, G.T. (1994) Electric Power Quality, 2nd edn, Stars in a Circle Publications, West Lafayette, IN 